\title{
Automation of Stone Feeding on T8 Honing Machine
}

\author{
Prof. Swapnil J. Patil ${ }^{1}$, Mr. Omkar R. Choukar ${ }^{2}$, Mr. Chaitrajeet R. Deokate ${ }^{3}$ \\ Asst., Prof., Mechanical Engineering Department, AGTI'S, Dr. Daulatrao Aher College of Engineering, Karad, India ${ }^{1}$ \\ Production Supervisor, SKF PVT. LTD., Pune, Maharashtra, India ${ }^{2}$ \\ GET, Pharma Design, GEA Process Engineering India PVT. LTD., Vadodra, Gujarat, India ${ }^{3}$
}

\begin{abstract}
Honing is an abrasive machining process that produces a precision surface on work piece by scrubbing an abrasive stone against it along a controlled path. Honing uses a honing stone or a hone, to achieve a precision surface. The hone is composed of abrasive grains that are bound together with an adhesive. It is used for surface finishing outer surface of the inner race and the inner surface of the outer race of taper roller bearings. It is bound to wear and tear. The honing stone is then manually adjusted so that the abrasive surface comes in contact with the material to be machined. Hence, the machine has to be stopped and the operator needs to adjust the stone accordingly. The stopping, adjusting and restarting of the machine increases the idle time of the machine. Therefore, it is necessary to automate this process. We will be using a position based process for the movement of the honing stone after the abrasive material is eroded by $2 \mathrm{~mm}$. This will decrease the idle time and increase the productivity.
\end{abstract}

Keywords: Honing, Bearings, Wear of stone, Automation.

\section{INTRODUCTION}

Honing is a cutting process where multi-edge tools coated techniques used for honing operation like Longitudinal with particles with continuous surface contact between the Stroke Honing, Short stroke honing, Centreless plunge tool and work piece are used to optimize the dimension, honing etc.

form and surface of pre-machined work pieces. Between Honing uses a special tool, called a honing stone or tool and work piece a change in direction of the a hone, to achieve a precision surface. The hone is longitudinal movement takes place. The finished surfaces composed of abrasive grains that are bound together with are characterized by a cross-hatch pattern on the surface.

The work process with honing is a combination of stroke and rotation movement of an expandable honing tool with inserted honing stones or diamond sticks. The result is the surface structure with cross-hatch pattern generated by the honing process. The timing of the honing is defined by quick cutting of the peaks of the pre-machined bore surface. This rapidly achieves a smoothing of the surface.

Applications: Finishing of cylinders for internal combustion engines, air bearing spindles and gears. There are many types of hones but all consist of one or more abrasive stones that are held under pressure against the surface they are working on.

SKF India has most important operation of Honing to be performed on internal side of outer race of bearing. After performing grinding on bearing material the honing gives perfect finishing to surface.

As rotation on roller or ball of bearing is necessary to be very smooth \& very easy to work with maximum efficiency. Bearing working principle depends on very smooth rolling of supporting rollers or balls. Honing allows to super finish the surface to make it very easy for motion with slight lubrication over it. There are different an adhesive. Generally, honing grains are irregularly shaped and about 10 to 50 micrometres in diameter (300 to 1,500 mesh grit). Smaller grain sizes produce a smoother surface on the workpiece.

A honing stone is similar to a grinding wheel in many ways, but honing stones are usually more friable so that they conform to the shape of the work piece as they wear in. To counteract their friability, honing stones may be treated with wax or sulphur to improve life; wax is usually preferred for environmental reasons.

\section{PROBLEM STATEMENT}

Installation of automatic stone feed mechanism in a T8 channel FTC honing machine.

In SKF honing is used for surface finishing operations of taper roller bearings. A silicon carbide honing stone is used. The stone wears out after machining of around 350 components. The stone has to be moved forward by required distance. Existing tool feeding system is a manual system, which terminates when stone wears out and to manually feed the stone, human efforts as well as time is required. It increases cycle time per product. It affects dimensional accuracy and quality of the product and also reduces the productivity. 
Vol. 4, Special Issue 1, January 2017

The system requires automation to get maximum For the mechanism of compensation of tool hydraulic efficiency while working without interruption due stone system is being finalised its design aspects are mentioned wear. To develop automatic clamping \& declamping unit below.

which can hold honing stone with desire pressure. There is need to develop a proper holding arrangement which can A. Hydraulic system

fit in specified area, which is less than internal diameter of For designing a hydraulic system the very first step is to outer race of ring on which operation is to be performed.

\section{OBJECTIVES}

1. To design and develop stone feeding system.

2. To validate it by its practical implementation on actually machining operation.

3. To check the differences between manual and automatic stone feeding machine so as to overcome loses.

4. To increase the number of components produced per batch.

\section{SCOPE}

Our scope during this project work was limited to mechanical system design.

1. To develop a mechanism to fulfill above mentioned objectives.

2. To design a mechanism without affecting the quality of honing.

Any work on PLC programming is within sponsor's scope.

\section{METHODOLOGY}

Following are the methodological steps that are taken to arrive at the desired results during this project.

1. Literature survey on existing scenario.

2. Problem definition.

3. Selection and finalization of mechanism.

4. Design and analysis of mechanism.

5. Fabrication of system.

6. Implementation of system.

7. Benchmarking of system.

\section{SELECTION OF MECHANISM}

After studying about various tool wear compensation techniques and building a basic understanding of the problems related to them, some mechanism are proposed to automate the existing feeding system. From past experience a wear of $2 \mathrm{~mm}$ was considered acceptable before the surface finish of bearing race started degrading. The two major steps to be done during this automation are 1. Detection of $2 \mathrm{~mm}$ tool wear.

2. Mechanism for compensation of this $2 \mathrm{~mm}$ tool wear.

This chapter describes in brief, all the proposed mechanisms along with their advantages and limitations. Finally, the approved mechanism is explained along with its design steps.

For detection of tool wear inductive proximity sensor was finalised as it had all the properties and application which are required to carry out the operation. prepare a basic logical circuit. To prepare this circuit a sequence of operations to be performed is required. Following is the practical sequence of operations to be followed to get the desired motion of tool.

- To sense the tool wear of about $2 \mathrm{~mm}$, this is done by inductive sensor.

- This sensor activates the piston cylinder arrangement and the piston moves forward such that it touches the tool. This is sensed by another inductive sensor.

- The sensor activates the clamping/declamping mechanism and finally declamps the tool.

- After the tool is declamped the feeding mechanism pushes the tool by $2 \mathrm{~mm}$.

- After the tool is feed by $2 \mathrm{~mm}$ the tool gets clamped.

Based on this sequence a hydraulic circuit is proposed as shown below.

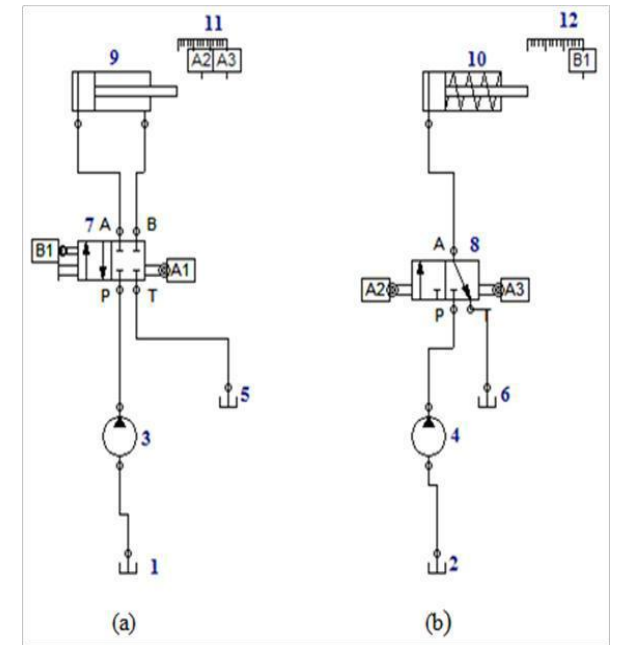

Fig 1 Proposed Hydraulic Circuit; (a) feeding circuit; (b) clamping circuit

B Components of Hydraulic circuit are as follows:

- 1, 2, 5, 6- Tank.

- 3, 4- Fixed displacement pump.

- 7-4/2 Direction Control Valve.

- 8-3/2 Direction Control Valve.

- 9- Double action cylinder.

- 10 - Single acting cylinder (spring retraction)

- 11, 12- Displacement rule.

- A1, A2, A3, B1, - Limit switches or Sensors.

When the honing stone tool wears about by $2 \mathrm{~mm}$, the inductive sensor gets activated. This activation of sensor is linked with direction control valve ${ }^{[7]}$ which allows the flow of fluid from tank to double acting cylinder ${ }^{[9]}$. Now 
IARJSET

International Advanced Research Journal in Science, Engineering and Technology

National Conference on Design, Manufacturing, Energy \& Thermal Engineering (NCDMETE-2017)

AGTI's Dr. Daulatrao Aher College Engineering, Vidyanagar Extension, Karad

Vol. 4, Special Issue 1, January 2017

the piston moves forward until it touches the tool. When it Hence the selected cylinder is safe.

touches the tool, sensor A1 and A2 activates. Sensor A1

then changes the spool position of direction control valve

[7] and sensor A2 changes the spool position of direction The maximum velocity assumed is $0.06667 \mathrm{~m} / \mathrm{s}$.

control valve ${ }^{[8]}$. Due to the change in position of direction Therefore discharge $\mathrm{Q}=$ Area $\mathrm{x}$ velocity.

control valve ${ }^{[7]}$ the cylinder gets locked into it current $7.85^{*} 10^{-3} \times 0.06667=31.42 \mathrm{lit} / \mathrm{min}$

position. Due to the change in position of $\mathrm{dcv}^{[8]}$ the single

acting spring loaded cylinder moves forward and de- G. Selection of Direction control valve:

clamps the tool. By the time it de-clamps sensor B1 gets Maximum flow required in hydraulic circuit is 31.42

$\mathrm{ON}$. This sensor $\mathrm{B} 1$ changes the position of $\mathrm{DCV}^{[7]}$, due lit/min and maximum pressure is 12.738 bar. Hence the to which the cylinder ${ }^{[9]}$ moves forward from is present Direction control Valve D2 is selected from the table.

position. The piston of cylinder ${ }^{[9]}$ now moves the tool by

$2 \mathrm{~mm}$. This movement of tool by $2 \mathrm{~mm}$ is sensed by A3

sensor. Sensor A3 then sends a signal due to which DCV

${ }^{[8]}$ changes the position. Now the piston of cylinder ${ }^{[10]}$ retracts due to opposite force of spring. Which means the tool has being clamped again and the honing cycle can be continued.

\section{Design of Hydraulic System}

The characteristics of all the components and their functioning should be considered while designing the system. Other important aspects which should be considered in design are:

- Safety of operation

- Performance of desired function

- Efficiency of operation

H. Selection of pump:

Maximum flow required in hydraulic circuit is 31.42 lit/min and maximum pressure is 12.738 bar hence pump must provide the required flow against the required pressure. From the table the P5 model of vane pump is selected because this satisfies our requirement.

\section{Selection of reservoir:}

Sizing of the reservoir from thumb rule formula is (3 to 4) x pump delivery/min.

$=3 \times 31.42=94.26$ liters.

Hence from the table the oil reservoir of model $\mathrm{T} 2$ is selected.

Table 1 designation and its capacity

The factors along with the task have to be considered with a view to arriving at the best possible design. Following are the assumptions made while designing the hydraulic circuit.

- The maximum force on cylinder piston is about $9.80 \mathrm{kN}$.

- The maximum stroke of cylinder is about $300 \mathrm{~mm}$.

- The maximum velocity of piston is to be about 0.0667 .

- The working pressure, maximum is about 50bar.

D. Selection of hydraulic actuator:

The maximum working pressure $=50 \mathrm{bar}$

Since $\mathrm{P}=\mathrm{F} / \mathrm{A}$.

$50 * 10^{5}=\frac{9.8 * 10^{3}}{\frac{\pi}{4} * d^{2}}$

$\mathrm{d}=49.96 \mathrm{~mm}$

Hence rod diameter $=50 \mathrm{~mm}$

From the table select rod diameter $=50 \mathrm{~mm}$.

And bore diameter corresponding to $50 \mathrm{~mm}$ is $100 \mathrm{~mm}$.

So A5 model of cylinder is selected

E. Check for maximum pressure:

Since total stroke of cylinder $=300 \mathrm{~mm}$

Full bore area $=\pi / 4 * \mathrm{D}^{2}=7.85^{*} 10^{-3}$

Where $\mathrm{D}=100 \mathrm{~mm}$.

And annulus area $=\pi / 4 *\left(\mathrm{D}^{2}-\mathrm{d}^{2}\right)=5.8875 * 10^{-3} \mathrm{~m}^{2}$

So the maximum pressure $=1$ oad $/$ area

$$
\begin{aligned}
& =\frac{9.8 \times 10^{3}}{7.85 \times 10^{-3}} \\
& =12.738 \mathrm{bar}
\end{aligned}
$$

\begin{tabular}{|c|c|c|c|}
\hline $\begin{array}{c}\text { Sr. } \\
\text { No. }\end{array}$ & $\begin{array}{c}\text { Name of } \\
\text { component }\end{array}$ & Model & Flow capacity \\
\hline 1 & $\begin{array}{c}\text { Suction } \\
\text { Strainer }\end{array}$ & S1 & $381 \mathrm{pm}$ \\
\hline 2 & DCV & D2 & $381 \mathrm{pm}$ \\
\hline 3 & Vane Pump & P5 & At 35bar, 37.51pm \\
\hline 4 & Cylinder & A5 & Bore $=100 \mathrm{~mm}$ \\
\hline & & rod $=50 \mathrm{~mm}$ \\
\hline 5 & Oil reservoir & T2 & $\begin{array}{c}\text { Capacity }=100 \\
\text { litres }\end{array}$ \\
\hline
\end{tabular}

J. Limitations of using hydraulic system

The pump runs continuously, and if the accumulator and the hydraulic cylinders are not in need of the fluid, a valve between the pump and accumulator dumps the excess fluid back into the reservoir.

So the energy consumption of the system is always on full throttle as soon as the pump is turned on. Any thoughts of turning the pump on only when one needs the pressurized fluids are dashed by the requirements of the systems.

The fluid needs to be warmed up and any bubbles removed. Bubbles of air are compressible, and would compromise the overall performance. This has been one of the limitations of hydraulic systems. 
IARJSET

International Advanced Research Journal in Science, Engineering and Technology

National Conference on Design, Manufacturing, Energy \& Thermal Engineering (NCDMETE-2017)

AGTI's Dr. Daulatrao Aher College Engineering, Vidyanagar Extension, Karad

Vol. 4, Special Issue 1, January 2017

\section{H. Ball Screw Actuator}

The ball screw drive is an assembly that converts rotary motion to linear motion (vice versa). It consists of a ball screw and a ball nut packaged as an assembly with recirculating ball bearings. The interface between the ball screw and the nut is made by ball bearings which roll in matching ball forms. With rolling elements, the ball screw drive has a very low friction coefficient and is typically greater than $90 \%$ efficient. The forces transmitted are distributed over a large no of ball bearings, giving a low relative load per ball comparatively.

\section{J. Selection of Ball Screw Actuator}

Selection of electric cylinder is based on diameter of spindle and required stroke length. Assuming the required stroke length to be approximately $200 \mathrm{~mm}$. Standard dimensions of the honing tool is $13.4 \times 12 \times 62 \mathrm{~mm}$.

- Therefore, effective cross-section area is $13.4 \times 12$ $\mathrm{mm}^{2}$.

- To find the max. diameter of spindle of the actuator,

$$
\frac{\pi}{4} d^{2}=13.4 \times 12
$$

- Therefore, $\mathrm{d}=14.31 \mathrm{~mm}$ (approx. 15mm). From the standard catalogue of cylinders (FESTO) available we select DNCE-32-200-BS-"10"P-Q [21].

Table 2 Designation of Selected Ball Screw Actuator

\begin{tabular}{|l|l|}
\hline Basic configuration feature & Value \\
\hline Function & $\begin{array}{l}\text { DNCE } \\
\text { cylinder }\end{array}$ \\
\hline Size & $32 \mathrm{~mm}$ \\
\hline Working stroke & $200 \mathrm{~mm}$ \\
\hline Variable stroke & $200 \mathrm{~mm}$ \\
\hline Drive type & BS Ball screw spindle \\
\hline Secured against rotation & $\begin{array}{l}\text { Q non rotating piston } \\
\text { rod }\end{array}$ \\
\hline Spindle diameter & $10 \mathrm{~mm}$ \\
\hline Piston rod thread & $\mathrm{M} 10 * 1.25$ \\
\hline Motor type & Stepper \\
\hline Max speed & $0.5 \mathrm{~m} / \mathrm{s}$ \\
\hline Max. drive torque & $0.8 \mathrm{Nm}$ \\
\hline Weight & $1.5 \mathrm{~kg}$ \\
\hline
\end{tabular}

Table 3 Specifications of Selected Ball Screw

\begin{tabular}{|c|c|}
\hline DNCE & Company's product code \\
\hline 32 & Size \\
\hline 200 & Stroke length \\
\hline BS & Ball screw \\
\hline “10" & Spindle diameter \\
\hline
\end{tabular}

K. Selection of Stepper Motor:

From specifications of electric cylinder maximum drive torque is found to be $0.8 \mathrm{Nm}$. This criterion is considered while selection of stepper motor for ball screw actuator. Based on this maximum torque limit, stepper EMMS-ST42-S-SE-G2 is selected. [21]

Table 4 Specifications of Selected Stepper Motor.

\begin{tabular}{|c|c|}
\hline Feature & Values \\
\hline Holding torque & $0.5 \mathrm{Nm}$ \\
\hline Max. rotational speed & $1740 \mathrm{rpm}$ \\
\hline Stepper angle & $1.8 \pm 5 \%$ \\
\hline Nominal Voltage & $48 \mathrm{~V} \mathrm{DC}$ \\
\hline Nominal Current & $1.8 \mathrm{~A}$ \\
\hline Weight & $0.45 \mathrm{~g}$ \\
\hline
\end{tabular}

After selecting the electric actuator and stepper motor, it is needed to select a compatible motor controller. From standard selection catalogue of FESTO, motor and controllers, CMMO-ST is selected. CMMO-ST is a closed-loop servo controller for stepper motors, equipped with various functions. It includes low heat development, monitored safe positions and smooth motor running curve. This sets the stepper motor controller CMMO-ST apart from conventional controllers of this type. Alternatively, the CMMO-ST can also function as a low-cost open-loop system with stepper motors without encoder. The extensive range of functions and the optimum price/performance ratio provides further advantages.

\section{BLOCK DIAGRAM OF HONING MACHINE STONE FEEDING MECHANISM}

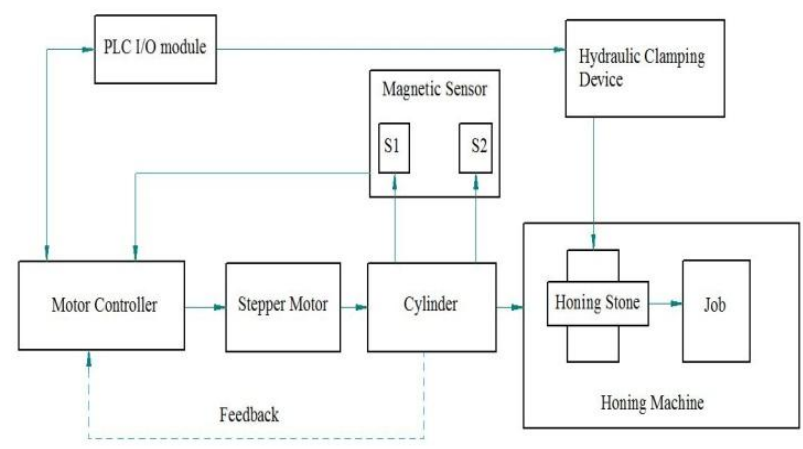

\section{DESIGN OF SUPPORT STRUCTURE FOR ACTUATOR}

A. Analysis of the Supporting Structure using ANSYS Static structural analysis of the designed supporting structure for electric actuator is done using ANSYS Workbench.

Following are the steps followed during the analysis.

Step 1: Meshing

The assembly of supporting structure is meshed using tetrahedrons with element size of $5 \mathrm{~mm}$. 


\section{IAR JSET}

International Advanced Research Journal in Science, Engineering and Technology

National Conference on Design, Manufacturing, Energy \& Thermal Engineering (NCDMETE-2017)

\section{AGTI's Dr. Daulatrao Aher College Engineering, Vidyanagar Extension, Karad}

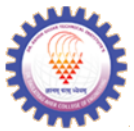

Vol. 4, Special Issue 1, January 2017

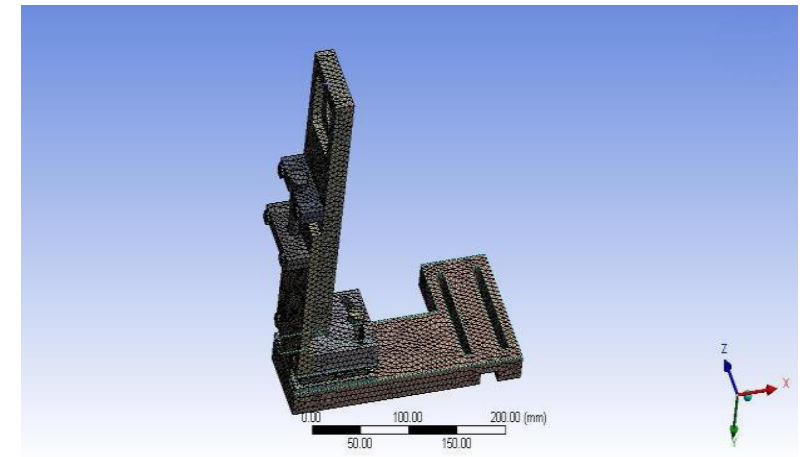

Fig 2 Meshing Support Structure.

\section{Step 2: Restricting DOF}

A fixed support is applied to the lower face of the base plate as shown.

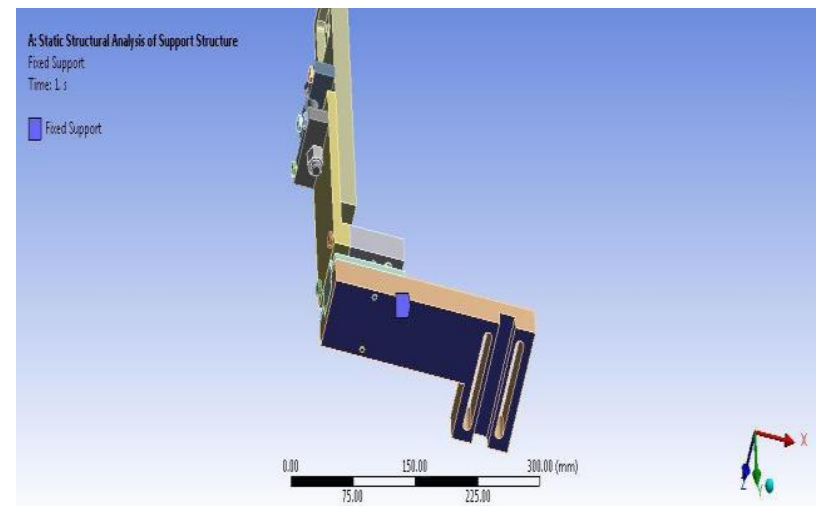

Fig 3 Fixed Support.

Step 3: Applying Moment

It is assumed that the combined weight $(20 \mathrm{~N})$ of electric actuator and stepper motor is concentrated at the end of electric actuator which is located at a distance of $150 \mathrm{~mm}$ from the holding column. Hence a moment of $3000 \mathrm{~N}-\mathrm{mm}$ is applied as shown.

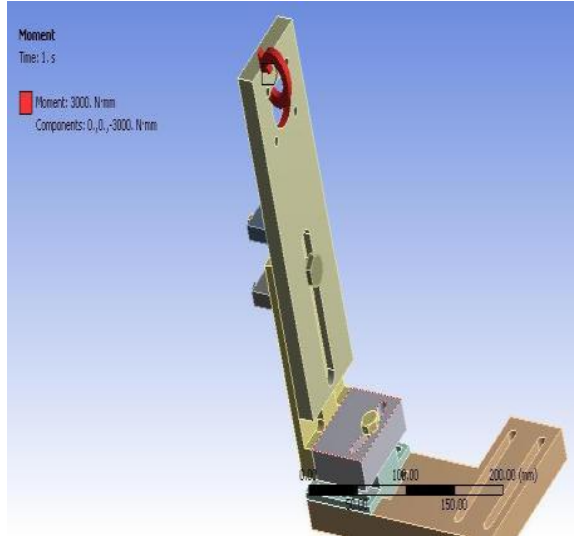

Fig 4 Applying Force

Step 4: Applying Force

A force of $20 \mathrm{~N}$ is applied on the bolt holes and actuator holding hole as shown in following figure.

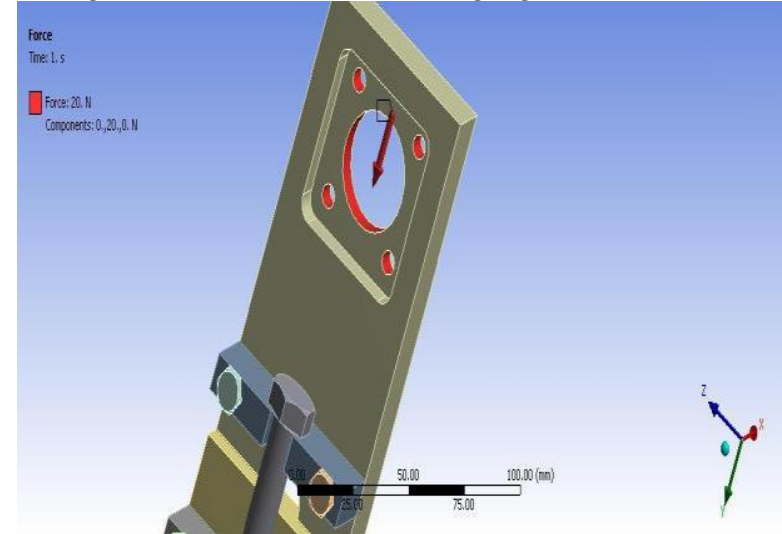

Fig 5 Applying Force.

Step 5: Applying Bolt Pre-tension

According to standards for low carbon steels (45C8) min proof strength is $225 \mathrm{MPa}$ [22]. The pre-tension on bolt will be $2 \mathrm{kN}$.

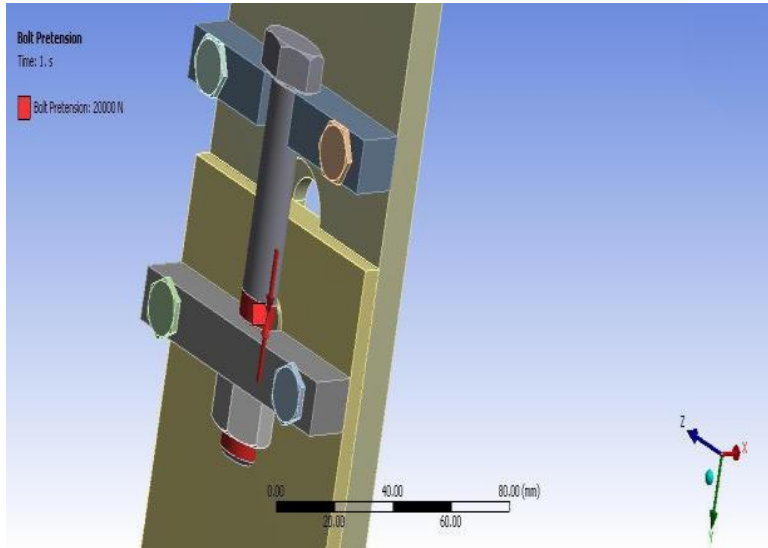

Fig 6 Bolt Pre-tensioning

Step 6: Solution

Following are the results obtained after solving.

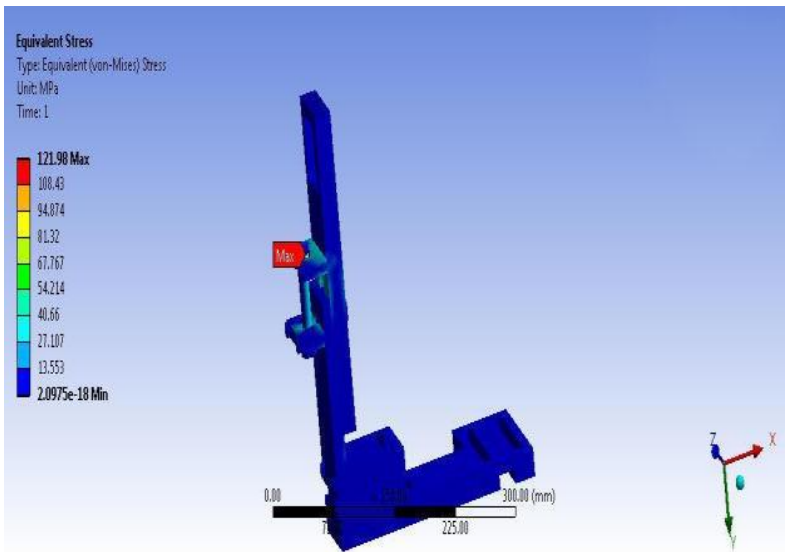

Fig 7 Equivalent Stress.

Material is taken as C45 and the yield strength of mild steel is taken as $380 \mathrm{Mpa}$. Considering a factor of safety of 


\section{IAR JSET}

International Advanced Research Journal in Science, Engineering and Technology

National Conference on Design, Manufacturing, Energy \& Thermal Engineering (NCDMETE-2017)

AGTI's Dr. Daulatrao Aher College Engineering, Vidyanagar Extension, Karad

Vol. 4, Special Issue 1, January 2017

2 we will get the allowable stress which will be $380 / 2=190 \mathrm{MPa}$. The equivalent stress obtained was less than the allowable stress. Hence the design is safe.

\section{DESIGNING}

\section{A. Design of Swivelling Arm}

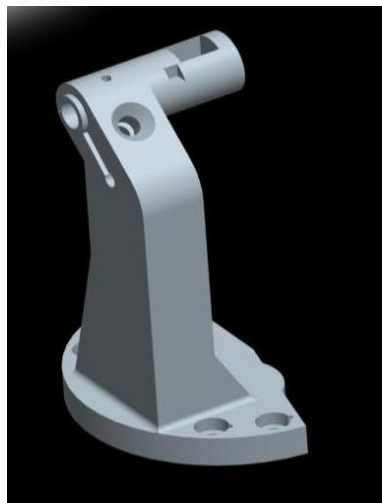

Fig 8- Image of swivelling arm

\section{DESIGNING A HYDRAULIC CLAMP}

A. Parameters to design Hydraulic Clamping Unit

1. The stone being feed to surface of bearing is pressure controlled.

2. The honing pressure control system requires stone to apply pressure of 2 bar on surface of Bearing being honed. 3. To maintain pressure of 2 bar at tip of honing stone, Clamping unit must put more than 2 bar pressure on stone holder so that it can sustain in honing operation.

4. Hydraulic clamp must hold the stone even after the declamping the stone for moving forward.

5. This states that hydraulic system requires two different pressure at two different conditions, that is one while honing operation is being performed on race of bearing \& another when stone is to be moved forward from clamp to match the honing requirement.

6. Two different pressure should be maintained by single clamp.

B. Proposed design for hydraulic clamp:

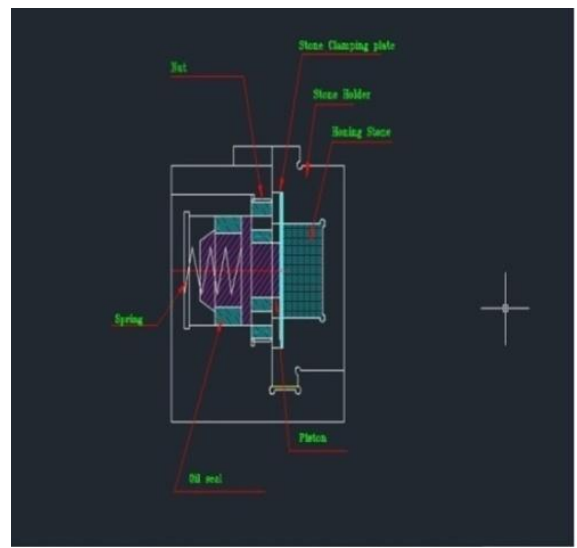

Fig 9 Front view of Hydraulic Clamp

C. Working of Proposed Design

1. Design Have Square clamping cavity when stone is to be fitted to be clamped.

2. A spring is fitted perpendicular to stone motion direction.

3. Spring applies force on plunger which pushes stone on another side to hold properly.

4. spring \& plunger are sealed unit where hydraulic seal is provided.

5. From hydraulic seal the hydraulic oil can come in, same will not leak to stone or bearing.

6. Hydraulic oil too applies pressure on (pressure plate) clamping plate. Which pressure is real clamping pressure.

D. Calculations For Hydraulic Clamp

Calculating the strength of a clamping nut used in manually operating machine.

Material used EN8

Yield strength $=465 \mathrm{~N} / \mathrm{mm}^{2}$

Maximum tensile stress $=700-850 \mathrm{~N} / \mathrm{mm}^{2}$

$0.2 \%$ proof stress $=450 \mathrm{~N} / \mathrm{mm}^{2}$

Hardness $=201 / 255$ Brinnel

Impact $\mathrm{KCV}=28$ joules

$\%$ of Carbon EN-8 = $0.36-0.44$

1) $\sigma_{t}=\frac{\text { Syt }}{\text { factor of safety }}$

$850 \mathrm{~N} / \mathrm{mm}^{2}=\frac{465 \mathrm{~N} / \mathrm{mm}^{2}}{\text { factor of safety }}$

Factor of safety $=0.547$

2) $\sigma_{\mathrm{t}}=\frac{P(\text { load })}{\frac{\pi}{4} d c^{2}}$

$850=\frac{P}{\frac{\pi}{4} \times 8.773}$

$\mathrm{P}=5856.753 \mathrm{~N}$

3) Finding Pressure required to clamp the stone

Considering torque required $750 \mathrm{~N}$-mm as it is applied by spanner and hand on nut head.

$\mathrm{T}=\frac{W d m}{2}\left(\frac{\mu \sec 30+\tan 25}{1-\mu \sec 30 \tan 25}\right)$

$750=\frac{W \times 0.9 \times 10}{2}\left(\frac{0.5 \times 1.54+0.0436}{0.423-0.0436}\right)$

$750=4.5 \mathrm{~W}\left(\frac{0.6206}{0.3794}\right)$

$458.71=4.5 \mathrm{~W}$

$\mathrm{W}=261.58 \mathrm{~N}$

$\mathrm{W} \approx 270 \mathrm{~N}$

Hence designing Hydraulic clamp for minimum pressure of $270 \mathrm{~N}$.

4.2.5 Calculations for Spring

$\mathrm{d}=0.8$

$\mathrm{P}=50 \mathrm{~N}$

$\delta=12 \mathrm{~mm}$

Spring material : Cold drawn steel wire.

Permissible Shear stress

$\tau=0.50$ Sut $=975 \mathrm{~N} / \mathrm{mm}^{2}$

[ Sut $=1950$ for Grade 2 for $\mathrm{d}=0.8$ ]

$\mathrm{C}=5 \quad \mathrm{D}=5$

Number of active coils: 


\section{IAR JSET}

International Advanced Research Journal in Science, Engineering and Technology

National Conference on Design, Manufacturing, Energy \& Thermal Engineering (NCDMETE-2017)

AGTI's Dr. Daulatrao Aher College Engineering, Vidyanagar Extension, Karad

Vol. 4, Special Issue 1, January 2017

$\delta=\frac{8 P D^{3} N}{G d 4}$

$\mathrm{N}=7.99=8$ coils

Free Length of Spring:

$\delta=\frac{8 P D^{3} N}{G d^{4}}=12 \mathrm{~mm}$

Total number of coils:

Assumed that spring has square and ground ends so the number of inactive coil is 2

$\mathrm{Nt}=\mathrm{N}+2=8+2=10$ coils

Solid length of spring:

$\mathrm{Ntd}=10(0.8)=8 \mathrm{~mm}$

Wahl factor :

$\mathrm{K}=\frac{4 C-1}{4 C-4}+\frac{0.615}{C}$

$\mathrm{K}=1.123$

It is assumed that there will be gap of $1 \mathrm{~mm}$ between consecutive coils when spring is subjected to maximum force.
Total number of coils is 10 .

Total axial gap between coils $=(10-1)=9 \mathrm{~mm}$

Free length $=$ solid length + total axial gap $+\delta$ $=8+9+12=12 \mathrm{~m}$

Pitch of coil $=\frac{\text { Free lengt } h}{(N t-1)}=\frac{29}{(10-1)}=3.22 \mathrm{~mm}$.

\section{EXPERIMENTAL VALIDATION}

\section{A. Stepper Motor Program Validation}

Stepper motor EMMS-ST-42-S-SE-G2 was programmed using a software developed by FESTO, Festo Configuration Tool. Following figure shows the record table created using FCT.

Table 5 Record Table for Stepper Motor Validation

\begin{tabular}{|c|c|c|c|c|c|}
\hline No. & Type & Target & Start condition & Velocity $(\mathbf{m m} / \mathbf{s})$ & Acceleration/ Deceleration(m/s2) \\
\hline 1 & PA & $140 \mathrm{~m}$ & Ignore & 100.00 & 1.000 \\
\hline 2 & FSL & $10.0 \%$ & Delay & 30.00 & 1.000 \\
\hline 3 & PRA & $0.00 \mathrm{~mm}$ & Ignore & 5.80 & 0.200 \\
\hline 4 & PRN & $2.00 \mathrm{~mm}$ & Ignore & 10.00 & 0.200 \\
\hline 5 & PA & $0.00 \mathrm{~mm}$ & Ignore & 100.00 & 0.200 \\
\hline
\end{tabular}

PA: Positioning to absolute position.

FSL: Force Control -stroke limit active.

PRA: Positioning relative to actual position.

PRN: Positioning relative to nominal position.

The above program was validated step by step:

- After initialization of the program first record was run and the cycle was stopped. The stroke length was measured using vernier caliper.

- For second record the actuator moved forward until it sensed $10 \%$ back force due to the presence of tool and it came to rest.

- In third record, current position of actuator was set as home position by the controller.

- Now the controller moves the actuator and hence the tool by $2 \mathrm{~mm}$ from the new home position. This was validated by marking initial position and final position on the tool and measuring it by vernier caliper.

- The fifth record sends a signal to controller to retract the actuator to absolute home position.

\section{IMPROVEMENT IN PRODUCTION}

Table 6 Production and Downtime per Shift.

\begin{tabular}{|c|c|c|}
\hline Parameter & Before & After \\
\hline Production per shift & 5000 & 5500 \\
\hline Machine Downtime per shift & $45 \mathrm{~min}$ & $25 \mathrm{~min}$ \\
\hline
\end{tabular}

Before implementation of new system the production per shift was 5000 bearing rings. Implementation of the new system has resulted in increase in production by 500 bearing rings per shift. 1 shift consists of $8 \mathrm{hr}$.

\section{CONCLUSION AND FUTURE SCOPE}

In this project, earlier the mechanism used for compensating the tool wear was manual, but after implementing the proposed mechanism it was successfully automated. Various parameters were measured to examine the new system. There was a significant decrease in the surface roughness value. Before implementing the newly automated honing machine stone feeding mechanism the surface roughness of the inner race of bearing ring was $0.16 \mu \mathrm{m}$ and now it is found out to be $0.14 \mu \mathrm{m}$.

By implementing the newly automated honing machine stone feeding mechanism the production of bearing rings was increased by 500 rings per shift. Earlier the production of bearing rings was 5000 rings per shift. This shows that the production has been increased by $10 \%$. It can be concluded that the machine downtime per shift earlier was 45 minutes which has been decreased to 25 minutes. Thus the total downtime of honing machine per shift was reduced by $45 \%$.

It can be seen that a wear of $2 \mathrm{~mm}$ in honing stone occurs approximately after honing 400 bearing rings. Thus, after every two shifts the operator will need to change the honing stone. This will result in machine downtime. If an automated mechanism is developed to replace the honing stone after it has been completely worn out, the machine downtime can further be reduced. Hence there is a future 


\section{IAR JSET}

International Advanced Research Journal in Science, Engineering and Technology

National Conference on Design, Manufacturing, Energy \& Thermal Engineering (NCDMETE-2017)

AGTI's Dr. Daulatrao Aher College Engineering, Vidyanagar Extension, Karad

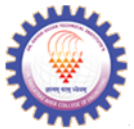

Vol. 4, Special Issue 1, January 2017

scope to automate the replacement mechanism of honing stone.

\section{ACKNOWLEDGEMENT}

It gives us a great sense of pleasure to present the report of the B.E Project undertaken during B.E. Final Year. We owe special debt of gratitude to Professor S.J.PATIL, and also to Mr Shyam Date plant head, Mr Manish Adhav SR. Manager Manufacturing Engg., Mr. D.S.Deepak, Asst. Manager, Mr Jacob Verghese General Manager HR, Department of Mechanical Engineering, Dr. Ashok Gujar Technical Institute's, Dr. Daulatrao Aher College of Engineering, Karad for his constant support and guidance throughout the course of our work. His sincerity, thoroughness and perseverance have been a constant source of inspiration for us. It is only his cognizant efforts that our endeavors have seen light of the day We also take the opportunity to acknowledge the contribution of Professor V. V. Rangate, Department of Mechanical Engineering, Dr. Ashok Gujar Technical Institute's, Dr. Daulatrao Aher College of Engineering, Karad for his full support and assistance during the development of the project.

We also do not like to miss the opportunity to acknowledge the contribution of all faculty members of the department for their kind assistance and cooperation during the development of our project. Last but not the least, we acknowledge our friends for their contribution in the completion of the project.

\section{REFERENCES}

[1] Dirk Bähre, C.Schmitt, U.Moos," Analysis of the Differences between Force Control and Feed Control Strategies during the Honing of Bores, 377 - 381, ( 2012 )

[2] The McGraw-Hill Companies, Production Technology, Bangalore: Tata McGraw-Hill Education Private Limited, 2011.

[3] H. Brunskill, P. Harper and R. Lewis, "The real-time measurement of wear using ultrasonic reflectometry," Wear, pp. 1129-1133, 2015.

[4] M. Malekian, S. S. Park and M. B. Jun, "Tool wear monitoring of micro-milling operations," Journal of Materials Processing Technology, pp. 4903-4914, 2009.

[5] S. Choudhury and P. Srinivas, "Tool wear prediction in turning," Journal of Materials Processing Technology, pp. 276-280, 2004.

[6] G. Zhang, S. To and G. Xiao, "Novel tool wear monitoring method in ultra-precision raster milling using cutting chips," Precision Engineering, pp. 555-560, 2014.

[7] A. Kassim, M. Mannan and Z. Mian, "Texture analysis methods for tool condition monitoring," ScienceDirect, pp. 1080-1090, 2007.

[8] D. D. Addona and R. Teti, "Image data processing via neural networks for tool wear prediction," ScienceDirect, pp. 252-257, 2013

[9] C. Scheffer, H. Kratz, P. Heyns and F. Klocke, "Development of tool wear-monitoring system for hard turning," International Journal of Machine Tools \& Manufacture, pp. 973-985, 2003.

[10] S. Dutta, S. Pal, S. Mukhopadhyay and R. Sen, "Application of digital image processing in tool condition monitoring: A review," CIRP Journal of Manufacturing Science and Technology, pp. 212232, 2013.

[11] E. Aligiri, S. Yeo and P. Tan, "A new tool wear compensation method based on real-time estimation of material removal volume in micro-EDM," Journal of Materials Processing Technology, pp.
2292-2303, 2010

[12] P. Bleys, J. Kruth, B. Lauwers, A. Zryd, R. Delprettl and C. Tricarico, "Real-time Tool Wear Compensation in Milling EDM".

[13] G. Bissacco, G. Tristo, H. Hansen and J. Valentincic, "Reliability of electrode wear compensation based on material removed per discharge in micro EDM milling," CIRP Annals - Manufacturing Technology, pp. 179-182, 2013.

[14] P. Bleys, J.-P. Kruth and B. Lauwers, "Sensing and compensation of tool wear in milling EDM," Journal of Materials Processing Technology, pp. 139-146, 2004.

[15] Y.-F. Chang and Z.-H. Chiu, "Electrode wear-compensation of electric discharge scanning process using a robust gap-control," Mechatronics, pp. 1121-1139, 2004.

[16] J.-Z. Li, L. Xiao, H. Wang, H.-L. Yu and Z.-Y. Yu, "Tool wear compensation in 3D micro EDM based on the scanned area," Precision Engineering, pp. 753-757, 2013

[17] D. Bahre, C. Schmitt and U. Moos, "Analysis of the Differences between Force Control and Feed Control Strategies during the Honing of Bores," SciVerse Science Direct, pp. 377-381, 2012.

[18] "Engineers Garage," $2016 . \quad$ [Online]. Available: http://www.engineersgarage.com

[19] "Dae Notes," 2016. [Online]. Available: http://www.daenotes.com/. R. Jain, "Surface Roughness," in Engineering Metrology, Delhi, Khanna Publishers, 2012, pp. 640-646.

[20] S. J. Derby, Design of Automatic Machinery, New York: Marcel Dekker, 2011

21] FESTO, "FESTO CATALOGUES," 2015. [Online]. Available: https://www.festo.com/cms/en-in_in/index.htm.

[22] "Fastenal,"June2009.[Online].Available:https://www.fastenal.com/c ontent/feds/pdf/Mechanical\%20Properties\%20of\%20M etric\%20fastners.pdf. [Accessed 2015].

23] FESTO, "Motors and controllers," 2013. [Online].

[24] Budynas-Nisbett, "Statically Loaded Tension Joint with Preload," in Shigley's Mechanical Engineering Design, USA, McGraw-Hill, 2008, p. 430. 